UDC 577.112:576.311.348:611.018.52

\title{
DYNAMICS OF THROMBIN-INDUCED EXPOSITION OF ACTIN ON THE PLATELET SURFACE
}

\author{
A. A. TYKHOMYROV \\ Palladin Institute of Biochemistry, National Academy of Sciences of Ukraine, Kyiv; \\ e-mail: artem_tykhomyrov@ukr.net
}

\begin{abstract}
Platelets play the key role in thrombosis and are also involved in angiogenesis as well as immune and reparative responses. In the function cascade, platelets undergo a complex cell processing, and subcellular fragments, not detectable in the resting state, are exposed on platelet surface after stimulation with agonists. This study has been performed to evaluate dynamic characteristics of actin exposition on the surface of plasma membrane of thrombin-activated platelets. Using flow-cytometric assay, it has been observed that the level of actin presented on activated platelets directly depends on agonist concentration. In the case of platelet stimulation with thrombin in the highest concentration $(1.0 \mathrm{U} / \mathrm{ml})$ taken for this study, the level of actin exposed on activated platelets was up to 4.4 times higher as compared with resting cells. Confirmation of the flow cytometry data for cell-surface actin on thrombin-activated platelets was achieved by direct visualization using a confocal laser scanning microscopy. Period of actin exposition appeared to be longer than the time phase corresponding to platelet secretion stage. Functional role of platelet surface actin has required further detailed studying, however, it is thought that superficial actin could interact with various blood plasma proteins, including plasminogen and its activators, serving as a binding site and/or center for their pericellular processing.
\end{abstract}

Key words: cell-surface actin, cytoskeleton remodeling, platelets, thrombin-induced activation, flow cytometry, confocal scanning microscopy.

$\mathrm{P}$ latelets are small circulating subcellular fragments playing pivotal role in haemostasis, and also involved in regulation of angiogenesis and immunological processes [1]. It is well-documented that activation of platelets with agonists leads to the reorganization of cytoskeleton resulting in drastic changes of platelet morphology [2]. The major component of platelet cytoskeleton is actin, which is presented in platelets in globular (soluble) G-form, polymerized (filamentous) F-form and associated in so called membrane cortex. Actin cytoskeleton is highly dynamic structure. During activation, rapid fibrillogenesis characterized by polymerization of G-actin and incorporation of membrane cortex actin into the filamentous network occurs [3]. Except maintaining platelet shape, actin microfilaments regulate granule fusion with the outer membrane, secretion of specific proteins, integrin-mediated adhesion, and signal transduction [4]. Besides intracellular reactions, stimulation of platelets with agonists causes exposition of functional molecules on platelet surface, which are not detectable in the resting state. Amongst these molecules, several cytoskeletal proteins appear on the outer surface of plasma membrane of activated platelets. For example, vimentin, a protein of intermediate filaments, has been detected on the surface of activated platelets. It has been demonstrated that cell-surface vimentin binds complex "vitronectin plasminogen activator inhibitor 1 (PAI-1)" via its $\mathrm{NH}_{2}$-terminus with high affinity $\left(K_{\mathrm{d}} \sim 80 \mathrm{nM}\right)[5]$. To the best of our knowledge, there are two studies, in which actin has been argued to be present on the surface of activated platelets $[6,7]$. However, issues concerning dynamic parameters of this process and time-dependent alterations in actin exposition are still in need of detailed evaluation. Actin, which is known to be the most abundant protein in the majority of eukaryotic cells, has been shown to be exposed on the surface of several cell types depending on their functional state [8]. Thus, it is obvious that actin may play important roles other than a cytoskeletal component in the cytoplasm, however, up to date, little is known about functional significance of the cell-surface actin, with the exception of two cases. Extracellular actin has been demon- 
strated to participate in angiostatin's generation from plasminogen/plasmin on the surface of some tumor cells [9]. Chromaffin cells of the adrenal cortex use exposed surface actin for chromagranin A processing yielding a set of regulatory peptides [10]. Therefore, seeking cell types, which express actin outside the plasma membrane, and establishing of potential functional role of actin in such "unexpected" location are still a large field for research.

In this study, highly sensitive methods (flow cytometry and confocal microscopy) with the use of specific antibody have been used to establish basic dynamic characteristics and time-dependent profile of actin exposition on the surface of thrombin-stimulated platelets.

\section{Materials and Methods}

Reagents. Human thrombin, rabbit anti-actin antibodies and secondary anti-rabbit FITC-conjugated IgG, BSA, paraformaldehyde, and sodium citrate have been purchased from Sigma (USA). HEPES, glucose, citric acid, sodium phosphates, sodium chloride, potassium chloride and magnesium chloride have been obtained from Helicon (Russia).

Blood platelets and platelet aggregation. Blood has been taken from 5 fasting healthy volunteers who had not taken any drugs for 14 days prior the study by antecubital vein puncture. Blood has been collected into one-tenth volume of citrate buffer (100 mM sodium citrate, $80 \mathrm{mM}$ citric acid, $110 \mathrm{mM}$ glucose) as anticoagulant. Washed platelets were obtained as described elsewhere [11]. Briefly, after centrifugation at $160 \mathrm{~g}$ for $20 \mathrm{~min}$ at $22{ }^{\circ} \mathrm{C}$, plateletrich plasma (PRP) has been harvested. Platelets were then pelleted by subjecting PRP to centrifugation at $340 \mathrm{~g}$ for $20 \mathrm{~min}$ at $22^{\circ} \mathrm{C}$. Platelet pellets have been resuspended in washing buffer, $\mathrm{pH}$ 6.8, containing $20 \mathrm{mM}$ HEPES, $137 \mathrm{mM} \mathrm{NaCl}, 4 \mathrm{mM} \mathrm{KCl}, 0.2 \mathrm{mM}$ $\mathrm{MgCl}_{2}, 0.2 \%$ glucose, and $0.2 \%$ BSA. Platelet pellets were washed twice with HEPES buffer, resuspended and pre-incubated for $5 \mathrm{~min}$ at $37^{\circ} \mathrm{C}$. Then, $3.0 \times 10^{5}-$ $3.5 \times 10^{5}$ platelets $/ \mu 1$ were taken for each aggregometry analysis. Platelet aggregation as a mark of platelet viability and activity was initiated by thrombin $(0.2$, 0.5 or $1.0 \mathrm{U} / \mathrm{ml}$, where $1.0 \mathrm{U} / \mathrm{ml}=1.0 \mathrm{NIH} / \mathrm{ml}$ ) and monitored for 5 min by lumi-aggregometer SOLAR AT-02 (Russia) using “Agregometr 2.01" software as previously described [12]. To evaluate whether intensity of actin exposition depends on thrombin concentration, $2.5 \times 10^{6}$ platelets have been taken and incubated with thrombin $(0.2,0.5$ or $1.0 \mathrm{U} / \mathrm{ml})$ for 1 h at $37^{\circ} \mathrm{C}$ at slight agitation. After completion of the period of thrombin incubation, platelets were fixed with $1 \%$ paraformaldehyde in sodium phosphate buffered saline (PBS), $\mathrm{pH} 7.0$, for $60 \mathrm{~min}$ at $4{ }^{\circ} \mathrm{C}$ to negate ability of platelets to internalize immunoglobulins [13]. The same amount of non-activated (resting) platelets was used as a control. Assessment of time profile of actin exposition was performed by incubation of platelets with $0.2 \mathrm{U} / \mathrm{ml}$ of thrombin. In this case, activation was stopped after 0.5 , 5, 30 and 60 min by paraformaldehide. To verify, if cell destruction could be a cause of actin-positive signal increment, resting platelets were processed exactly as it was described above and incubated for the maximal period (60 min) and then analyzed cytometrically. In one sample series the exposure of activation-dependent actin was measured by a flow cytometric assay. In parallel, cell-surface actin was visualized with the use of laser confocal microscopy.

Flow cytometry and confocal microscopy. Fixed platelets were washed with sodium-citrate (3.8\%)-PBS and sodium-citrate (3.8\%)-PBS containing 1\% BSA. Meanwhile, anti-actin antibody and anti-rabbit FITC-IgG were mixed in PBS in dilution of 1:80 and 1:200, respectively (according to manufacturer recommendations) and left at $37^{\circ} \mathrm{C}$ for $30 \mathrm{~min}$. Then, platelets were incubated with antibody mixture for $30 \mathrm{~min}$ at $4{ }^{\circ} \mathrm{C}$. Platelets incubated only with FITC-conjugated antibody were used as a control for non-specific IgG binding. After staining, platelets were washed from unbound antibodies twice with PBS by centrifugation at $1000 \mathrm{~g}$ for $3 \mathrm{~min}$ at $4{ }^{\circ} \mathrm{C}$. Washed platelets were resuspended in $1 \mathrm{ml}$ of PBS and immediately measured with using of Coulter Epics XL (Beckman Coulter, USA). For each analysis, at least 10000 FITC-positive particles were analyzed for relative FITC fluorescence intensities with medium or low analyzing rate and at $488 \mathrm{~nm}$ excitation wave length within the FL1 channel set at logarithmic gain (1594 Volts, Gain - 1.0). Intensities of FITC fluorescence were counted as arbitrary units for comparison between signals from control, thrombin-untreated and thrombin-activated platelets. Finally, cytometry data were presented graphically, and signal intensity obtained from control platelets was taken as $100 \%$.

Parallel platelet samples have been subjected to confocal laser microscopy with using of Carl Zeiss LSM 510 Meta (Carl Zeiss, Germany). Briefly, 25-30 $\mu$ l of suspension of platelets were stained and washed in the regimes that were mentioned above at 
room temperature in darkness and then were mountained on the glass slide, coversliped and immediately analyzed. Laser with $488 \mathrm{~nm}$ wave length was used for fluorophore excitation, the emission was detected by the channel $>505 \mathrm{~nm}$. Stained resting platelets have been used to threshold for background fluorescence intensity. Electronic shutters and image acquisition were under the control of Zeiss ZEN 2009 Light Edition software.

Statistical Analysis. The statistics were performed with the use of nonparametric $U$-test of Mann-Whitney. Differences between arbitrary units of FITC signal in each group of resting and activated platelets have been considered to be significant at $\mathrm{P}$ less than 0.05 .

\section{Results and Discussion}

Aggregometry has provided evidence of functional activity of platelets exposed to $0.2,0.5$ or $1.0 \mathrm{U} / \mathrm{ml}$ of thrombin, showing approximately 9,17 , and $40 \%$ of aggregated cells, respectively (Fig. 1). The level of spontaneously activated platelets has not exceeded 3\%.

Flow cytometry has indicated that there were no significant differences between actin content on membranes of resting platelets and control cells (platelets not incubated with anti-actin antibodies). However, 2.2, 2.7 and 4.4-fold increase in actin expression is observed on the surfaces of activated platelets and platelet micro-aggregates compared with control $(P<0.05)$ in the cases of $0.2,0.5$ or $1.0 \mathrm{U} / \mathrm{ml}$ of thrombin exposure, respectively (Fig. 2, $A, B)$.

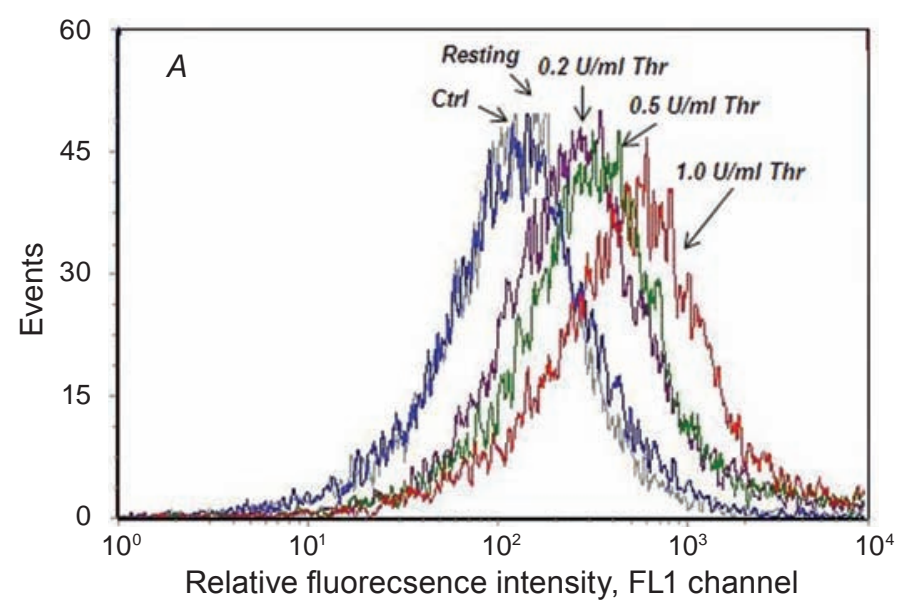

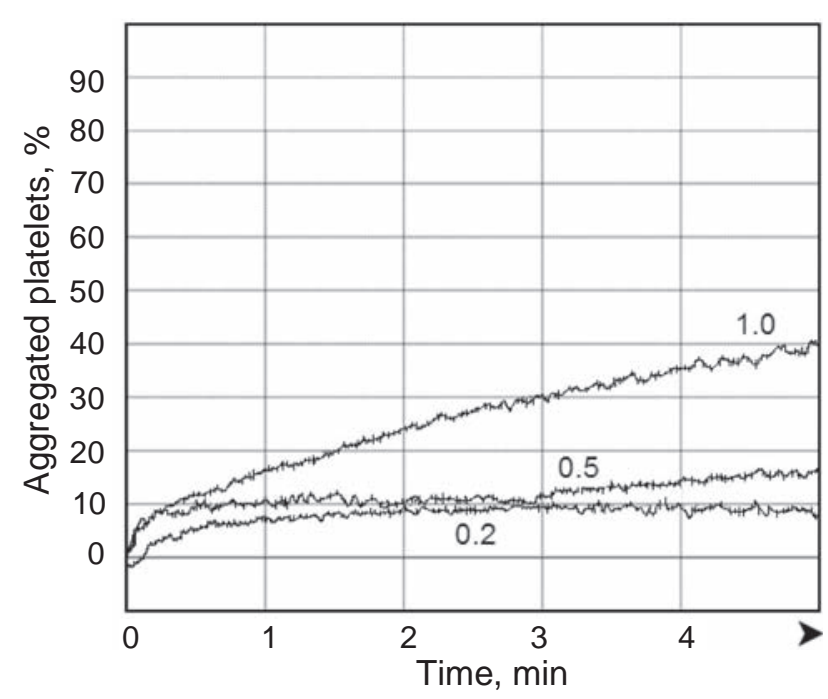

Fig. 1. Aggregation profiles for platelets activated with $0.2,0.5$ or $1.0 \mathrm{U} / \mathrm{ml}$ of thrombin (Thr)

Thus, changes of actin level on the outer side of platelet plasma membrane appear to be directly dependent on thrombin concentration and are in parallel with intensity of platelet aggregation shown by optic aggregometry analysis. These changes were confirmed by observations made with using of confocal microscopy (Fig. 3).

Slight FITC-positive signal produced by resting platelets may reflect the population of spontaneously activated cells (panel a). It is noted that preferentially single actin-positive cells are seen in the case of resting platelets (panel a) and platelets activated with $0.2 \mathrm{U} / \mathrm{ml}$ of thrombin (panel b), while large microsized aggregates are also observed together with in-

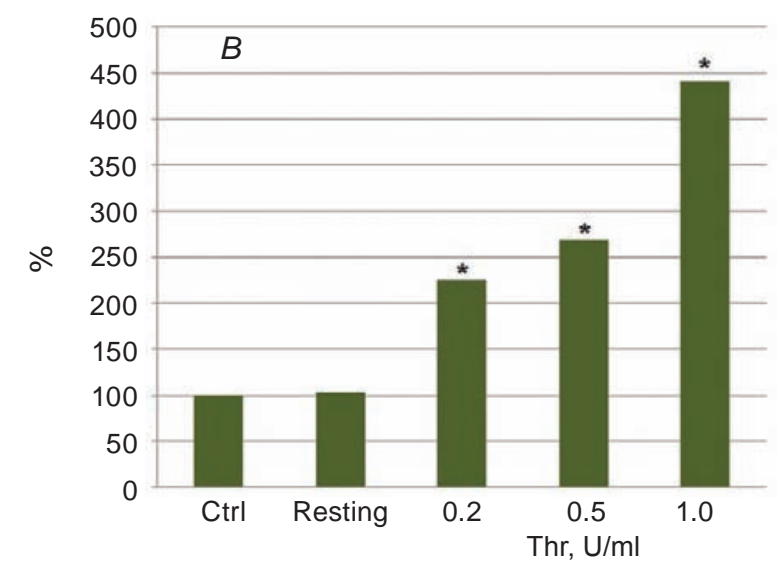

Fig. 2. Thrombin-dependent exposition of actin on the surface of platelets and their aggregates. A - platelets were gated on actin-positive events. $B$ - dynamic of thrombin-induced changes of actin exposition on the surface of platelets and their aggregates. Thr - thrombin. ${ }^{*} P<0.05$ vs. control (Mann-Whitney U-test) 

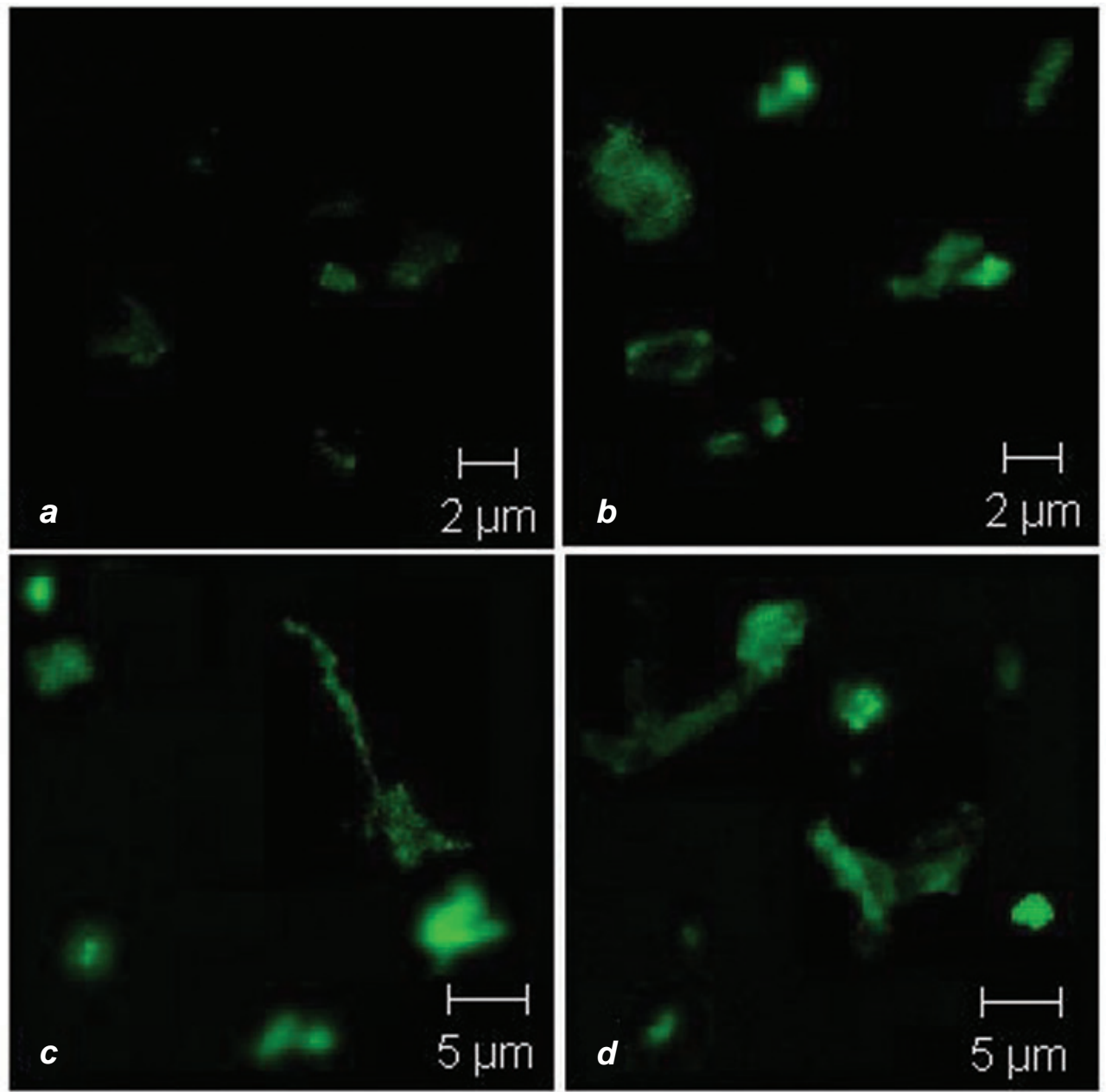

Fig. 3. Immunofluorescence confocal microscopy of platelets and their aggregates exposing actin (a - resting state, $b-0.2 \mathrm{U} / \mathrm{ml}$ thrombin, $c-0.5 \mathrm{U} / \mathrm{ml}$ thrombin, $d-1.0 \mathrm{U} / \mathrm{ml}$ thrombin)

dividual cells when platelets were incubated with 0.5 (panel c) or $1.0 \mathrm{U} / \mathrm{ml}$ (panel d) of thrombin. Mostly, actin has appeared to be uniformly localized around the whole surface of platelets that is in agreement with earlier data obtained on monocytic cell line U 937 [14].

Further, the lowest concentration of thrombin was taken for discovering kinetics of actin expression on the platelet surface. It is known that thrombin in such low concentrations is able to activate platelets without their significant aggregation [1] that is also obviously seen from aggregometry data (Fig. 1). Thus, low amounts of thrombin could be useful to detect minimal changes in cell-surface antigen composition induced by agonist. Flow cytometry demonstrated growth of actin levels on the platelet surfaces through the whole period of incubation from 0.5 to $60 \mathrm{~min}$ (Fig. 4). It is important to note that significant elevation of actin level on the surface of activated platelets is already observed in the first minutes after thrombin addition that is synchronized in time with activation-induced secretion [4]. However, the increase of cell-surface actin level is evident up to 60 min of incubation with thrombin, thus attributing later actin exposition to processes other than secretion.

Critically, detection of actin could be due to the cell damage during preparation procedures or adsorption of actin released from destructed cells on the platelet membrane. Experiments were designed to exclude each of these possibilities. In order to rule out artifactual results, resting platelets were incubated for the longest period (60 min) and subjected by exactly the same procedures as activated platelets. No significant increment in actin-positive signal was observed when thrombin non-treated platelets were analyzed with flow cytometry (less than $10-15 \%$ compared with control) (Fig. 2 and 4), thus 


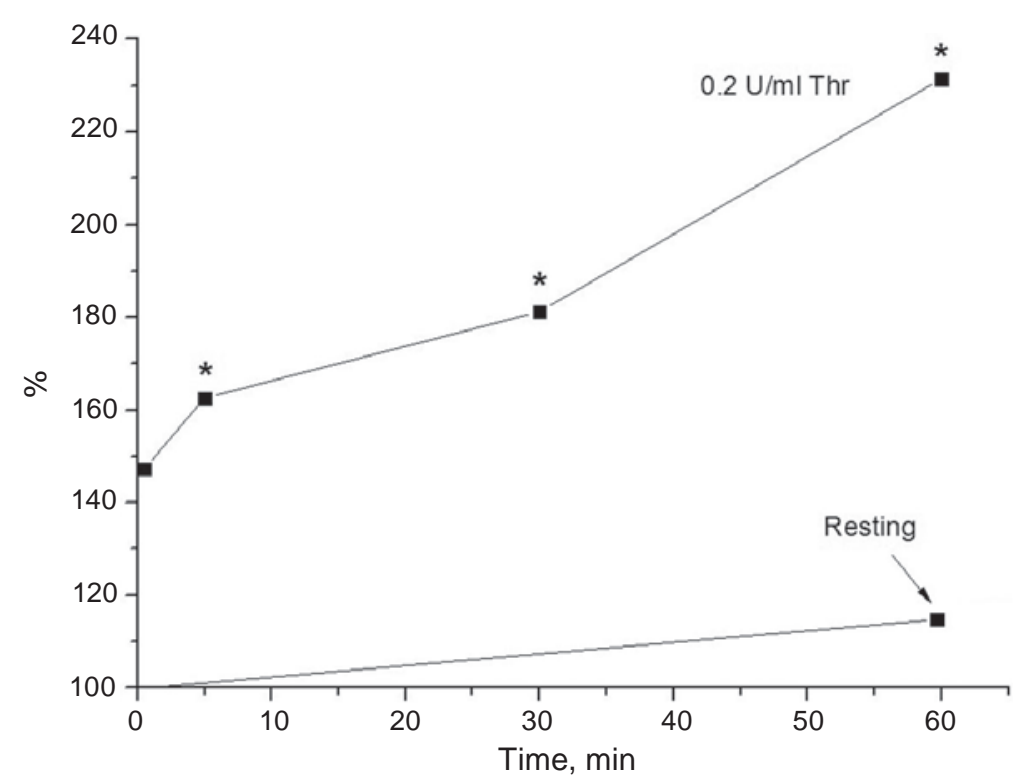

Fig. 4. Time-dependent profile of thrombin-induced actin exposition on the surface of platelets activated with $0.2 \mathrm{U} / \mathrm{ml}$ of thrombin for 0.5, 1.0, 30 and $60 \mathrm{~min}$. Thr - thrombin. ${ }^{*} P<0.05$ compared with each previous time point (Mann-Whitney U-test)

indicating that release of actin due to the loss of cell integrity may hardly be considered as the main cause of actin-positive response. Using of paraformaldehyde-fixed cells guarantees the absence of internalization of immunoglobulins by platelets. In addition, available data confirm that membrane surfaces of most cells (and furthermore, washed platelets) are not capable of sorbing plasma-circulating actin [15].

Actin is the most abundant of all the platelet proteins. The concentration of actin in a platelet is $0.55 \mathrm{mM}$, which translates into approximately two million copies per platelet. Of these molecules, 800000 assemble to form the 2000 to 5000 linear actin polymers that form the cytoskeleton of the resting cell. Platelet activation triggers cytoskeletal remodeling that can lead to morphology changes, exocytosis, microparticle generation, adhesion, aggregation, and retraction [1,3]. Thrombin is a potent platelet activator in vivo and in vitro. Thrombin communicates with platelets through a unique class of cell-surface protease activated receptors (PARs) that are members of a large family of $\mathrm{G}$ protein-coupled transmembrane domain receptors [16]. In addition to its well-characterized effects on intracellular signaling cascades, resulting in platelet degranulation and aggregation, thrombin also induces cellsurface expression of several molecules, including the adhesion molecule P-selectin and CD40 ligand, and activation of the integrin $\alpha \operatorname{IIb} \beta 3$, which binds fibrinogen and von Willebrand factor (VWF) to mediate aggregation [17]. The results obtained in the present work indicate that, among other functional molecules, which appear on the platelet surface due to thrombin-induced activation, actin may be one of the most cryptic.

There is a growing body of information concerning existence of actin at the external face of the cell surface in B-lymphocytes, monocytes, endothelial cells, smooth muscle cells, spermatozoa, chromaffine cells of adrenal cortex, fibroblasts, pericytes, some tumour cells. It is important to note that all known actin isoforms $(\alpha, \beta$, and $\gamma)$ have been found to be exposed by various cell types [see 8 , 18, 19 for review]. It is evident that actin may fulfil "unusual" functions having been exposed on the surface of certain blood cells. Actin is present on the surface of B-lymphocytes and, to a much lesser extent, on T-lymphocytes [20]. Moreover, the presence of cell-surface actin is regulated by the physiological state of cell. This is supported by the facts that transformed or mitogen-stimulated lymphocytes expose substantially more cell-surface actin than intact lymphocytes [15]. In contrast, resting monocytes U-937 expose actin, while their activation leads to the disappearance of this protein out of the membrane surface [14]. Earlier, authors of two papers have shown concomitant changes in antigen spectrum of activated platelets and assumed that actin could appear 
on the platelet surface $[6,7]$. However, up to date, neither principal characteristics nor mechanisms of this process have been assessed yet.

It is possible that the appearance of actin on the outside of the plasma membrane is rather associated with changes in phospholipid composition of the latter and the formation of lipid rafts induced by agonist action [21] than with granule secretion. An additional area worthy of particular consideration is related to the possible direct role of the surfaceassociated cytoskeletal protein in platelet interaction and cooperation, though whether platelets utilize cell-surface actin for regulation of clot formation or other physiological processes is unknown. It is likely that superficial actin could interact with various blood plasma proteins, including plasminogen and its activators, serving as a binding site and/or center for their pericellular processing. For example, actin mediates autoproteolysis of plasminogen/plasmin to angiostatins on cancer cells [9]. It is of interest that platelets are able not only to sequester angiostatins [22], but also to produce these angiogenesis inhibitors on their plasma membrane [23-25], and it is likely that exposed extracellular actin plays a similar role in this process. At least, it has been established that one more platelet cytoskeletal protein, vimentin, which is also found extracellulary, is of great significance, binding the complex vitronectinPAI-1 [5]. Two isoforms of $\beta / \gamma$-actin provided major plasminogen binding sites responsible for stimulation of plasminogen activation on catecholaminergic cells. Cell-surface actin is involved in plasmin-mediated processing of prohormone chromogranin A to a specific peptide that inhibits nicotinic-mediated catecholamine release [10]. These observations, identifying exposed actin as a specific binding site for plasminogen on catecholaminergic cells, thus suggest a broad paradigm for regulating neurotransmitter secretion within the neuroendocrine system. Further, sperm cells could serve as another example that may confirm a suggestion of functional crossroad between cell-surface actin and pericellular zymogene converting into active proteinases. Liu et al. [26] have recently shown that an average of $9.4 \%$ of motile sperms expose actin on the surface of head and acrosome, and this percentage is significantly correlated with the ability of sperm to bind to the zona pellucida of oocyte. It has been shown that actin exposed on the surface of sperm is not directly involved as a sperm receptor for binding in the zona pellucida because the addition of anti-actin antibody does not inhibit sperm binding with zona pellucida but effectively blocks acrosomal reaction after the spermatozoa had bound to the zona.

Finally, results obtained in this study indicate cell-surface actin as the fourth actin pool of the platelet (in addition to the three well-known forms G-actin, F-actin and actin of membrane cortex). It may be assumed that actin appearance on the platelet surface may be important for the process of clot formation and final retraction of the blood clot, being the consequence of cytoskeletal rearrangements and membrane changes. Relationship between thrombin concentration taken for platelet activation and intensity of actin exposition has been established. It has been also demonstrated for the first time that actin translocation on the platelet surface is not limited to the agonist-induced secretion period. Since platelets participate in many normal and pathophysiological processes, apart from haemostasis, including angiogenesis, inflammation, tissue reparation, and immune response, actin-bearing population of activated platelets may reflect pool of platelets performing some specific functions, thus further investigations in this area are required.

Acknowledgements. The author gratefully appreciates Dr. D. D. Zhernossekov, S. I. Diordieva, Y. M. Roka-Moya and A. J. Labyntsev for excellent technical assistance. This work was supported by grant for young scientists of the Palladin Institute of Biochemistry of NAS of Ukraine.

\section{ДИНАМІКА ТРОМБІН- ІНДУКОВАННОГО ЕКСПОНУВАННЯ АКТИНУ НА ПОВЕРХНІ ТРОМБОЦИТІВ}

\section{А. О. Тихомиров}

$$
\begin{gathered}
\text { Інститут біохімії ім. О.В.Палладіна } \\
\text { НАН України, Київ; } \\
\text { e-mail: artem_tykhomyrov@ukr.net }
\end{gathered}
$$

Тромбоцити відіграють ключову роль у процесах тромбоутворення, а також залучаються до регуляції ангіогенезу, імунної відповіді та репаративних процесів. Під час свого функціонування тромбоцити зазнають складних змін, при цьому субклітинні структури, які не виявляються у стані фізіологічного спокою, експонуються на поверхню тромбоцитів після їхньої активації агоністами. Метою цього дослідження було оцінити динамічні характеристики ек- 
спонування актину на поверхні плазматичної мембрани тромбінактивованих тромбоцитів. За допомогою протокової цитометрії показано, що рівень актину, який представляють активовані тромбоцити, безпосередньо залежить від концентрації агоніста. Зокрема, стимулювання тромбоцитів тромбіном $(1.0 \mathrm{U} / \mathrm{ml})$ призвело до збільшення рівня експонування актину у 4,4 раза у порівнянні 3 неактивованими клітинами. Встановлено, що інтенсивність експонування актину прямо залежить як від концентрації тромбіну, так і від часу інкубації 3 агоністом. Результати, одержані за допомогою протокової цитометрії, було підтверджено в ході безпосередньої візуалізації поверхневого антигену 3 використанням конфокальної лазерної скануючої мікроскопії. Функціональне значення поверхневого актину тромбоцитів потребує подальших досліджень, однак, припускається, що актин, локалізований на плазматичній мембрані, може взаємодіяти з різними протеїнами плазми, виступаючи як сайтом зв'язування, так i/aбо центром їх позаклітинного процесингу.

К лючов в с лова: актин поверхні клітин, ремоделювання цитоскелета, тромбоцити, тромбініндукована активація, протокова цитометрія, конфокальна скануюча мікроскопія.

\section{ДИНАМИКА \\ ТРОМБИНИНДУЦИРОВАННОГО ЭКСПОНИРОВАНИЯ АКТИНА НА ПОВЕРХНОСТИ ТРОМБОЦИТОВ}

\author{
А. А. Тихомиров \\ Институт биохимии им. А. В. Палладина \\ НАН Украины, Киев; \\ e-mail: artem_tykhomyrov@ukr.net
}

Тромбоциты играют ключевую роль в процессах тромбообразования, а также вовлекаются в регуляцию ангиогенеза, иммунного ответа и репаративных процессов. Во время своего функционирования тромбоциты претерпевают сложные изменения, при этом субклеточные структуры, которые не обнаруживаются в состоянии физиологического покоя, экспонируются на поверхность тромбоцитов после их активации агонистами. Целью данного исследования было оценить динамические характеристики экспонирования актина на поверхности плазматической мембраны тромбинактивированных тромбоцитов. С помощью проточной цитофлуориметрии было показано, что уровень актина, представленный активированными тромбоцитами, напрямую зависит от концентрации агониста. В частности, стимулирование тромбоцитов тромбином $(1.0 \mathrm{U} / \mathrm{ml})$ привело к увеличению уровня экспонированного актина в 4,4 раза по сравнению с неактивированными клетками. Результаты, полученные с помощью проточной цитометрии, были подтверждены в ходе непосредственной визуализации поверхностного антигена с использованием конфокальной лазерной сканирующей микроскопии. Время, в течение которого тромбоциты оказываются способными экспонировать актин, превышает период, соответствующий фазе секреции. Функциональное значение поверхностного актина тромбоцитов требует дальнейшего детального изучения, однако, предполагается, что актин, локализованный на плазматической мембране, может взаимодействовать с различными протеинами плазмы, выступая как сайтом связывания, так и/или центром их внеклеточного процессинга.

К л ю ч е вы е с лова: актин поверхности клеток, ремоделирование цитоскелета, тромбоциты, тромбининдуцированная активация, проточная цитометрия, конфокальная сканирующая микроскопия.

\section{References}

1. Michelson A. D. Platelets (the third edition). Academic Press, 2012. 1398 p.

2. Hartwig J. H. The platelet: form and function. Semin. Hematol. 2006;43(1):94-100.

3. Fox J. E. The platelet cytoskeleton. Thromb. Haemost. 1993;70(6):884-893.

4. Thon J. N., Italiano J. E. Platelets: production, morphology and ultrastructure. Handb. Exp. Pharmacol. 2012;210:3-22.

5. Podor T. J., Singh D., Chindemi P., Foulon D. M., McKelvie R., Weitz J. I., Austin R., Boudreau G., Davies R. Vimentin exposed on activated platelets and platelet microparticles localizes vitronectin and plasminogen activator inhibitor complexes on their surface. J. Biol. Chem. 2002;277(9):7529-7539.

6. George J. N., Lyons R. M., Morgan R. K. Membrane changes associated with platelet activation. Exposure of actin on the platelet 
surface after thrombin-induced secretion. J. Clin. Invest. 1980;66(1):1-9.

7. Tschoepe D., Spangenberg P., Esser J., Schwippert B., Kehrel B., Roesen P., Gries F. A. Flow-cytometric detection of surface membrane alterations and concomitant changes in the cytoskeletal actin status of activated platelets. Cytometry. 1990;11(5):652-656.

8. Tykhomyrov A. A. Interaction of actin with plasminogen/plasmin system: mechanisms and physiological role. Biopolymers Cell. 2012;28(6):413-423.

9. Wang H., Doll J. A., Jiang K., Cundiff D. L., Czarnecki J. S., Wilson M., Ridge K. M., Soff G. A. Differential binding of plasminogen, plasmin, and angiostatin 4.5 to cell surface beta-actin: implications for cancer-mediated angiogenesis. Cancer Res. 2006;66(14):72117215.

10. Miles L. A., Andronicos N. M., Baik N., Parmer R. J. Cell-surface actin binds plasminogen and modulates neurotransmitter release from catecholaminergic cells. J. Neurosci. 2006;26(50):13017-13024.

11. Gear A. R., Suttitanamongkol S., Viisoreanu D., Polanowska-Grabowska R. K., Raha S., Camerini D. Adenosine diphosphate strongly potentiates the ability of the chemokines MDC, TARC, and SDF-1 to stimulate platelet function. Blood. 2001;97(4):937-945.

12. Roka-Moya Y. M., Zhernossekov D. D., Grinenko T. V. Plasminogen/plasmin influence on platelet aggregation. Biopolymers Cell. 2012;28(5):352-356.

13. Verheul H. M., Lolkema M. P., Qian D. Z., Hilkes Y. H., Liapi E., Akkerman J. W., Pili R., Voest E. E. Platelets take up the monoclonal antibody bevacizumab. Clin. Cancer Res. 2007;13:5341-5347.

14. Por S.B., Cooley M.A., Breit S.N., Penny R., French P.W. Antibodies to tubulin and actin bind to the surface of a human monocytic cell line, U937. J. Histochem. Cytochem. 1991;39(7):981985.

15. Bachvaroff R. J., Miller F., Rapaport F. T. Appearance of cytoskeletal components on the surface of leukemia cells and of lymphocytes transformed by mitogens and Epstein-Barr virus. Proc. Natl. Acad. Sci. USA. 1980;77:49794983.
16. De Candia E. Mechanisms of platelet activation by thrombin: a short history. Thromb. Res. 2012;129(3):250-256.

17. Stalker T. J., Newman D. K., Ma P., Wannemacher K. M., Brass L. F. Platelet signaling. Handb. Exp. Pharmacol. 2012;210:59-85.

18. Smalheiser N. R. Proteins in unexpected locations. Mol. Biol. Cell. 1996;7(7):1003-1014.

19. Arnoys E. J., Wang J. L. Dual localization: proteins in extracellular and intracellular compartments. Acta Histochem. 2007;109(2):89110.

20. Owen M. J., Auger J., Barber B. H., Edwards A. J., Walsh F. S., Crumpton M. J. Actin may be present on the lymphocyte surface. Proc. Natl. Acad. Sci. USA. 1978;75(9):4484-4488.

21. Gousset K., Wolkers W. F., Tsvetkova N. M., Oliver A. E., Field C. L., Walker N. J., Crowe J. H., Tablin F. Evidence for a physiological role for membrane rafts in human platelets. J. Cell Physiol. 2002;190(1):117-128.

22. Klement G. L., Yip T. T., Cassiola F., Kikuchi L., Cervi D., Podust V., Italiano J. E., Wheatley E., Abou-Slaybi A., Bender E., Almog N., Kieran M. W., Folkman J. Platelets actively sequester angiogenesis regulators. Blood. 2009;113(12):2835-2842.

23. Jurasz P., Alonso D., Castro-Blanco S., Murad F., Radomski M.W. Generation and role of angiostatin in human platelets. Blood. 2003;102(9):3217-3223.

24. Jurasz P., Santos-Martinez M. J., Radomska A., Radomski M. W. Generation of platelet angiostatin mediated by urokinase plasminogen activator: effects on angiogenesis. J. Thromb. Haemost. 2006;4(5):1095-1106.

25. Radziwon-Balicka A., Moncada de la Rosa C., Zielnik B., Doroszko A., Jurasz P. Temporal and pharmacological characterization of angiostatin release and generation by human platelets: implications for endothelial cell migration. PLOS One. 2013;8(3):1-11.

26. Liu D. Y., Clarke G. N., Baker H. W. Exposure of actin on the surface of the human sperm head during in vitro culture relates to sperm morphology, capacitation and zona binding. Hum. Reprod. 2005;20(4):999-1005.

Received 15.08.2013 